\title{
Perinatal transmission of hepatitis C virus: an update
}

Mortada H.F. El-Shabrawi ${ }^{1}$, Naglaa M. Kamal ${ }^{1}$, Engy A. Mogahed ${ }^{1}$, Mona A. Elhusseini², Mohamed F. Aljabri ${ }^{3}$

\author{
'Department of Pediatrics and Pediatric Hepatology, Faculty of Medicine, \\ Cairo University, Egypt \\ 2Department of Obstetrics and Gynecology, Red Crescent Hospital, Cairo, Egypt \\ ${ }^{3}$ Department of Pediatrics and Pediatric Neurology, Alhada Armed Forces Hospital, \\ Taif, Saudi Arabia
}

Submitted: 6 March 2018

Accepted: 2 September 2018

Arch Med Sci 2020; 16 (6): 1360-1369

DOI: https://doi.org/10.5114/aoms.2019.83644

Copyright $\odot 2019$ Termedia \& Banach

\begin{abstract}
Infection with hepatitis C virus (HCV) is a major health problem worldwide. A large proportion of perinatal HCV infections are silent and may present later in adulthood with long-term complications. HCV has no effective immune prophylaxis and hence appropriate follow-up of all infants born to $\mathrm{HCV}$-infected mothers is necessary. Universal antenatal screening for HCV is largely debatable. Intrauterine and partum transmission of HCV are both possible and higher rates are associated with a high maternal serum viral load (> $10^{6}$ copies per milliliter), concomitant HIV infection, prolonged or difficult delivery, and invasive fetal monitoring during delivery. Infection during pregnancy and infancy needs to be investigated more in order to design management strategies for perinatal transmission of HCV most effectively. The recently approved new-generation, oral, direct-acting antiviral drugs may open a new era in HCV therapy for pregnant women and infected infants if proved to be safe during conception and infancy.
\end{abstract}

Key words: hepatitis C virus, perinatal transmission, vertical transmission, children, direct-acting antiviral drugs.

\section{Introduction}

Hepatitis C virus (HCV) infection is a major health problem all over the world. It can cause chronic hepatitis and liver cirrhosis and represents the main risk factor of primary hepatocellular carcinoma [1]. It is estimated to chronically affect $\sim 3 \%$ of the world's population ( 170 million people), with more than one million new cases annually [1]. There is great variability in HCV prevalence rate from one country to another and even within the same country from one region to another [2]. Moreover, there are controversies between researchers as some of them suggested a decreasing trend of HCV prevalence [3] while others expected an increasing burden $[4,5]$.

Percutaneous inoculation is the commonest mode of HCV transmission, but sexual, household, occupational, and vertical transmission can also occur [6]. Nowadays, HCV is the main indication for adult liver transplantation [7]. Until 2011, the historically accepted standard of care therapy was pegylated interferon (Peg-IFN) and ribavirin (RBV), producing a sustained virologic response in almost half of the patients for

\author{
Corresponding author: \\ Naglaa M. Kamal MD \\ Department of \\ Pediatrics and \\ Pediatric Hepatology \\ Faculty of Medicine \\ Cairo University \\ Cairo, Egypt \\ Phone: +96 6565580081 \\ E-mail: Nagla.kamal@ \\ kasralainy.edu.eg
}


genotype 1 and higher rates up to $50 \%$ for other genotypes [8].

When considering the health burden and dynamics of HCV infection, pregnant women and their infants represent a group with special physiological changes which can cause a modified course of chronic HCV and subsequently needs special considerations [9].

Recently, HCV has emerged as the most important cause of chronic viral hepatitis in children in many countries. Before universal screening of blood and blood products, which started in 1992, HCV was transmitted mostly through transfusions and organ transplants [10]. Nowadays, and especially in developed countries, perinatal transmission of HCV is considered the main cause of HCV infection in children [11]. Perinatal transmission leads to acquisition of HCV very early in life - in the intrauterine period (antenatal/antepartum), during delivery (natal/intrapartum) or after delivery (postnatal/postpartum) - with the consequence of chronic liver disease and liver cancer in early adulthood [12, 13]. Seropositive children at 18 months of age or older are generally believed to have been perinatally infected with HCV. Testing for HCV-RNA is essential to differentiate those with chronic infection from those who have spontaneously cleared the virus [14]. Screening of pregnant women who do not have known risk factors for infection as a method of prevention of perinatal transmission has remained a great challenge owing to the unavailability of HCV vaccine and the lack of an approved antiviral therapy during pregnancy [15].

Some authors hypothesize that routine prenatal HCV screening to identify HCV-infected women unaware of their infection may lead to performing other interventions during labor and in the perinatal period, reducing the risk of mother-to-infant transmission [16].

Pegylated interferon and ribavirin are no longer recommended for treatment of adults [17]. The advent of the newly available treatment regimens based on very effective and well-tolerated direct-acting antiviral agents (DAAs) will probably change the whole image dramatically [15].

\section{Epidemiology}

\section{Worldwide HCV infection prevalence in pregnant women}

The general HCV infection prevalence in pregnant females in the world is around $1-8 \%$. Perinatal transmission occurs from infected mothers to their offspring in 3-10\% of cases [18-21], with 10,000-60,000 new pediatric perinatal infections per year in developed countries [9].

The European Pediatric HCV Network reported that HCV-PCR testing has low sensitivity at birth which increases to $70-85 \%$ after 1 month of age [22]. This is partially explained by the very low viral loads in the first month of life and the wide incubation period of HCV that may extend up to 6 months. Therefore, a negative PCR test at birth is not a true indicator of the infant's HCV infection status. On the other hand, a negative PCR test after 12 months of age should be confirmed with anti-HCV, which is considered the gold standard, to detect children who have achieved spontaneous viral clearance [9].

In pregnant women, the prevalence of HCV infection varies considerably from one part of the world to another, $0.5-2 \%$ in high income countries and $5-15 \%$ in developing countries [23-25] with $3-10 \%$ perinatal HCV transmission to their offspring [26-38]. Consequently, the pediatric HCV infection rate is very low in developed countries (0.05-0.36\%), it increases to $1.8-5.8 \%$ in some developing countries, and is maximum in Egypt, Sub-Saharan Africa, the Amazon Basin and Mongolia. A higher seroprevalence (10-20\%) has been reported among children with other risk factors of exposure such as those treated for malignancies, or undergoing hemodialysis or surgery [28-30]. The HCV prevalence among pregnant women in Europe, the Americas and Asia is shown in Table I [39-72].

\section{HCV prevalence among pregnant women in Arab countries}

$\mathrm{HCV}$ infection is a serious health problem in Arab countries, with very wide variability in prevalence rate from one country to another, 0.4-23\% $[34,35]$, owing to different levels of development of health care systems and awareness, and availability of budget and resources [33] (Table I).

\section{HCV prevalence among pregnant women in African countries}

Africa is geographically divided into 5 regions (Table I) with heterogeneity in religion, culture and practices, and with a high human immune-deficiency virus (HIV) burden in sub-Saharan areas. Arab countries lie at the northern region. Most of the countries in the other four regions suffer from political conflicts, military confrontations, droughts and famines, leading to large numbers of internally and externally displaced people which might increase the prevalence of sexually transmitted diseases [73].

A systematic review and meta-analysis study published in 2015, conducted in 21 sub-Saharan African countries, found that the overall HCV prevalence among pregnant women in antenatal clinics was $3 \%$ and was $2 \%$ in the Central African region [74]. 
Table I. HCV prevalence among pregnant women in Arab and African countries

\begin{tabular}{|c|c|c|}
\hline Country & $\mathrm{HCV}$ prevalence in pregnant women & Special comment \\
\hline America & $\begin{array}{l}\text { In the United States, the estimated prevalence } \\
\text { of antenatal HCV infection is } 1-2.5 \% \text {; some } \\
\text { studies estimate the prevalence to be as high } \\
\text { as } 4 \%[39,40] \\
\text { In Brazil, HCV prevalence in young pregnant is } \\
0.098 \% \text { [41] }\end{array}$ & - \\
\hline Europe & $\begin{array}{c}\text { Variable }[42] \text { from } 0.1 \% \text { in Slovenia [ } 43] \text { to } \\
0.8 \% \text { and } 0.9 \% \text { in the United Kingdom and } \\
\text { Norway respectively }[44,45]\end{array}$ & $\begin{array}{c}\text { In the general population of Serbia about one } \\
\text { quarter of human immunodeficiency virus } \\
\text { (HIV) infected persons also have HCV co- } \\
\text { infection [46] }\end{array}$ \\
\hline Asia & $\begin{array}{l}\text { The highest prevalence of HCV is noted in } \\
\text { Central Asia (3.8\%), East Asia }(3.7 \%) \text {, and } \\
\text { North Africa/Middle East }(3.6 \%)[47,48]\end{array}$ & - \\
\hline $\begin{array}{l}\text { Saudi Arabia } \\
{[35,36,49]}\end{array}$ & $0.7 \%$ & - \\
\hline Yemen [37] & $8.5 \%$ & - \\
\hline $\begin{array}{l}\text { Syria, Jordan and } \\
\text { Lebanon [35] }\end{array}$ & No data & $\begin{array}{l}\text { This reflects underestimation of the magnitude } \\
\text { of the problem in this region [35] }\end{array}$ \\
\hline Iraq [38] & $3.21 \%$ & - \\
\hline Egypt $[50,51]$ & $8.6 \%$ & $\begin{array}{l}\text { Egypt is one of the areas of highest prevalence } \\
\text { of HCV among the population in general and } \\
\text { pregnant women in particular }[50,51] \text { with } \\
\text { genotype } 4 \text { being predominant }(90 \%)[52]\end{array}$ \\
\hline Sudan [53-55] & $0.6 \%$ & $\begin{array}{l}\text { Prevalence in pregnant women }(0.6 \%) \text { is lower } \\
\text { than that of the general population }(2.2-3.0 \%) \\
{[53-55]}\end{array}$ \\
\hline $\begin{array}{l}\text { Libya and } \\
\text { Maghreb region }\end{array}$ & $\begin{array}{l}\text { Lowest in Libya [56-58] (<1\%), followed by } \\
\text { Tunisia [59-62], the Kingdom of Morocco [59, } \\
\text { 63], Algeria [59], and Mauritania [64-66] }\end{array}$ & $\begin{array}{c}\text { Genotype } 4 \text { is the most prevalent in Libya, } \\
\text { which is the same as in Egypt, while genotype } 1 \\
{[57,61,62,64] \text { is predominant in the rest of }} \\
\text { Maghreb countries, like the nearby western } \\
\text { countries [58] } \\
\text { HCV prevalence variation might be explained } \\
\text { by the interaction with western countries } \\
\text { in Maghreb countries with more open } \\
\text { communities than in Libya [58] }\end{array}$ \\
\hline Eastern Africa & $\begin{array}{c}2-2.9 \%[65] \text { in some reports, and } 0 \% \text { to } 2 \% \text { in } \\
\text { others [66] }\end{array}$ & $\begin{array}{c}\text { Studies of HCV prevalence are scarce and } \\
\text { controversial [65] }\end{array}$ \\
\hline Southern Africa & Has not been well studied [65] & $\begin{array}{l}\text { Endemicity estimates put the region in the } \\
\text { intermediate group [65] }\end{array}$ \\
\hline Central Africa & $\begin{array}{l}\text { Prevalence is } 4.3 \% \text { among pregnant women } \\
{[68-70]}\end{array}$ & $\begin{array}{l}\text { One of the most heavily infected parts of the } \\
\text { world, reaching }>13 \% \text { in some countries [67]. } \\
\text { Cameroon has the highest prevalence (13.8\%), } \\
\text { followed by Burundi (11.3\%) and Gabon (9.2\%) } \\
{[67]}\end{array}$ \\
\hline Western Africa & $\begin{array}{l}\text { The prevalence among pregnant women is } 3 \% \\
\text { in Nigeria [71] and } 2.2 \% \text { in Burkina Faso [72] }\end{array}$ & Highly endemic for HCV $[71,72]$ \\
\hline
\end{tabular}

\section{Natural history of HCV infection in infected pregnant women}

Pregnancy is considered a state of relative immunodeficiency [75], especially T-cell mediated immunity [76], with a shift in the Th1/Th2 balance toward the Th2 response, and expansion of regulatory T-cells [23], to safeguard against rejection of the newly developing embryo by the maternal immune system [77]. This alteration in the immune system directly alters the natural course of HCV infection, giving more room for the virus to replicate while suppressing its immune-mediated damage to hepatocytes, which is demonstrated by the surprising finding of increasing viral RNA load with concomitant decreasing ALT levels [23, 78, 79].

It was reported that estrogen suppresses the intra-thymic T-cell differentiation while activating the extra-thymic pathways during pregnancy [80, 
81]. After delivery, the maternal immune system regains its baseline activity with the resultant decrease in viral load and increase in immune-mediated hepatocyte damage and consequently ALT level [82]. Spontaneous resolution of HCV viremia postpartum has also been reported [9].

Interestingly, greater rates of viral clearance after pregnancy were reported, compared to a non-pregnant control group, which can be attributed to the loss of pregnancy-induced physiological immunosuppression with a surge in maternal cellular immune activation with a decrease in Th2 activity and a rebound increase in Th1 activity, combined with fewer viral quasispecies, resulting in the clearance of HCV infection [83, 84]. Several reports have recommended initiating antiviral therapy at this time, augmenting the natural defense mechanism [9].

Another maternal obstetric complication of $\mathrm{HCV}$ is the earlier and more frequent development of cholestasis in HCV infected than non-infected women, which could be attributed to the altered transport of sulfated hormones in the liver, a failure in the transport of toxic substances, and a defect of the bile salt export pump [24, 85-87].

\section{Natural history of HCV infection in perinatally infected children}

It is believed that maternal HCV infection can affect the babies in different ways:

1. It can lead to increased incidence of intrauterine growth retardation, low birth weight, a higher neonatal intensive care admission rate and more frequent need for ventilatory support [88]. Other authors found no evidence to support that $[84,89,90]$.

2. It was found by Berkley et al. [91] that babies born to anti-HCV positive mothers were more likely to have neonatal abstinence syndrome when adjusted for the dose of methadone used. This may be due to the poor metabolism of methadone in the HCV-infected liver; hence, a considerably higher dose is transferred transplacentally compared to women who are not infected.

3. Perinatal infection may happen as the presence of reactive neutralizing antibodies in the mother does not prevent perinatal HCV transmission or progression to chronicity in infants and children. The timing of perinatal transmission of $\mathrm{HCV}$ is based on the appearance of HCV-RNA positivity in the newborn [92].

Perinatal infection can lead to: i) chronicity in $80 \%$ of cases [77], moreover, the appearance of cross-reactive neutralizing antibodies during the chronic phase does not correlate with better control of viremia or with the clearance of HCV [92], ii) a wide range of variability of ALT levels in the first year of life, when high values may be found, indicating acute hepatitis $[92,93]$.

\section{Biology and genetics of perinatal HCV transmission}

Other authors attributed the biology of perinatal transmission of HCV to the infection of maternal peripheral blood mononuclear cells (PBMCs) by the virus and to the presence of the negative strand of HCV inside the PBMC, which is a sign of viral replicative activity [94].

It was noted that HLA antigen class II diversity between the mother and the baby induces rapid clearance of infected maternal cells through the newborn alloimmune anti-major histocompatibility complex response; this was demonstrated to be protective for perinatal transmission of HCV [95]. A biologically reasonable explanation has been provided for these apparently contradictory results involving the important role of the interaction between HLA antigen class II molecules and CD4+ $T$ lymphocytes in the immune response and in allo-recognition [95].

With regard to single nucleotide polymorphisms of interleukin (IL)-28B that have been demonstrated to be important in determining spontaneous and treatment-induced clearance of HCV in children and in adults [96-98] recently, neither the mother's nor the children's IL-28B status was associated with an increased risk of perinatal transmission [98].

High levels of NK cells in the placenta of HCV-positive mothers were detected by some researchers [99]. These cells had greater cytotoxicity in the HCV-positive mothers. This may be an explanation for the relatively low rates of vertical transmission, though the increased cytotoxicity of the NK cells may also lead to a higher risk of preterm delivery [9].

\section{Risk factors of HCV perinatal transmission}

Although HCV perinatal transmission is lower than that of HBV and HIV [32, 100-102], it has a disadvantage, there being no currently available vaccines that can prevent or reduce its transmission [23, 103], with almost $33 \%$ of the infected children acquiring infection intrauterine and up to 50\% intrapartum [104].

There are many factors that can increase or decrease the risk of HCV perinatal infection, as shown in Table II [105-124]. It has to be kept in mind that viremia per se is a risk factor for perinatal transmission independently of HCV RNA levels $[17,125]$. As a consequence, each condition associated with the possible contact of HCV-infected maternal blood with the fetus or the newborn can be theoretically considered a risk factor [126]. 
Table II. Factors affecting the risk of HCV perinatal transmission

\begin{tabular}{|c|}
\hline Factors increasing the risk of HCV perinatal transmission: \\
\hline $\begin{array}{l}\text { High maternal serum viral load at the time of delivery as it indicates active viremia }[18-20,105,106] \text {. The risk is } \\
\text { proportionate to the increase in levels of viral load above } 105 \mathrm{IU} / \mathrm{ml}[19,107] \text { and reaches a maximum at levels } \\
\text { above } 107 \mathrm{IU} / \mathrm{ml}[108]\end{array}$ \\
\hline $\begin{array}{l}\text { High maternal serum ALT levels in the } 12 \text { months before pregnancy and/or at the time of delivery as it is } \\
\text { considered a reflection of higher viral replication rate }[23,101] \text { that may cause more extensive hepatic damage } \\
\text { and subsequently elevated ALT }[79,109-111]\end{array}$ \\
\hline Rupture of membranes > $6 \mathrm{~h}[9,23,86,107]$ \\
\hline Prolonged and/or difficult deliveries [112] \\
\hline $\begin{array}{l}\text { Fetal sex remained the only risk factor significantly associated with HCV perinatal transmission, with girls as } \\
\text { twice as likely to be infected as boys in one study [113] and } 8 \text { to } 3 \text { in another study [114]. This finding likely } \\
\text { reflects hormonal or genetic differences in susceptibility or response to infection. Maternal infections increase } \\
\text { fetal cortisol and dehydro-epiandrosterone synthesis [115]. Androgens may influence the immune response } \\
\text { [116]; estradiol protects stimulated feline lymphocytes from apoptosis, and human male and female fetuses } \\
\text { exhibit differences in regulation of the cytokine network [113] }\end{array}$ \\
\hline Twin pregnancies discordant for transmission of HCV are another supporting factor [117] \\
\hline Use of invasive procedures during pregnancy such as amniocentesis, although its impact is still debatable $[23,77]$ \\
\hline $\begin{array}{l}\text { Studies reported conflicting findings on the effect of invasive fetal monitoring }[9,18,118] \text {. Some authors } \\
\text { suggested that there is higher risk of HCV exposure with the use of scalp electrodes }[19]\end{array}$ \\
\hline Concomitant HIV infection: \\
\hline $\begin{array}{l}\text { - Increases risk by } 3 \text { - to } 4 \text {-fold [19, 119-121] } \\
\text { - A meta-analysis showed that HIV and HCV co-infection increases the odds of HCV perinatal transmission by } \\
90 \% \text { [121] } \\
\text { - The incidence of HCV vertical transmission is approximately 3-5\% in HCV RNA-positive mono-infected } \\
\text { mothers, but can be as high as } 19 \% \text { in HIV-co-infected [9] } \\
\text { - Even when controlling HIV, presence of HCV viremia increases the odds of vertical transmission } 2.82 \text {-fold. } \\
\text { This is thought to be attributed to the higher HCV load in immunosuppressed HCV/HIV-co-infected women } \\
\text { than in women with HCV infection only [122] }\end{array}$ \\
\hline Factors decreasing the risk of HCV perinatal transmission: \\
\hline $\begin{array}{l}\text { Specific HLA markers such as HLA D13 and HCV-specific CD4 reactivity decrease transmission, highlighting the } \\
\text { potential importance of immune-mediated mechanisms in HCV spread }[123,124]\end{array}$ \\
\hline $\begin{array}{l}\text { High NK cells in the placenta. These cells had greater cytotoxicity in the HCV-positive mothers. This may be an } \\
\text { explanation for the relatively low rates of vertical transmission; however, the increased cytotoxicity of the NK } \\
\text { cells may also lead to a higher risk of preterm delivery in HCV-positive mothers [9] }\end{array}$ \\
\hline
\end{tabular}

On the other hand, some factors seem to play no role in HCV perinatal transmission, such as HCV genotype [23], intrauterine device (IUD) insertion [18], and past history of liver disease, blood or blood products transfusion, and hepatitis during pregnancy. Also, no consistent relation was observed between the presence or absence of HCV infection in the first versus the second or subsequent infants [105], even in identical twins [127].

\section{Breast feeding and HCV perinatal transmission}

Although HCV-RNA is detectable in colostrums [31] and theoretical transmission may be possible through breast feeding, discouraging breast feeding in HCV-infected mothers is not recommended $[9,23,79,86,128]$, as there is no proof of any increase in the risk of HCV transmission with breast-feeding [105]. The European Paediatric
Hepatitis C Virus Network [21] noted no difference in infection rates in breast-versus formula-fed infants in a study carried out on 1,758 infants born to HCV-infected mothers.

Most researchers found that the HCV viral count in breast milk is extremely low and that it likely becomes inactivated in the digestive tract of the infants [129-133].

The risk increases if there is exposure to maternal blood with breast-feeding if the mother has cracked or bleeding nipples [9].

On the other hand, human breast milk may even have a protective antiviral role against HCV transmission. Pfaender et al. [134] designed an interesting study using a productive cell culture system to show that HCV infectivity is markedly decreased after incubation with human breast milk. They studied the effect of variables including HCV genotype, temperature, and milk from different species on the breast milk antiviral effect 
and they found that it was independent of any of those variables. Integrity of the viral envelope was impaired and free fatty acids, likely produced by the action of milk lipase, are responsible for the reduction in viral infectivity. Lipases present in human milk (lipoprotein lipase and bile salt stimulated lipase) produce products that are incorporated into the viral envelope, destroying viral integrity and decreasing its infectivity. Thus, milk digestion products released in the stomach might be able to inactivate residual viral particles, which otherwise could be transmitted upon breastfeeding [134].

\section{Mode of delivery and HCV perinatal transmission}

The effect of the mode of delivery on HCV perinatal transmission is controversial. Some authors suggested that with vaginal delivery, there is increased risk of HCV transmission to the baby due to increased risk of exposure to virus-contaminated maternal blood. Consequently, cesarean section may hypothetically be a better option [135].

Four large studies [18, 19, 118, 129] were carried out on 2,080 mothers and their infants, comparing the HCV transmission risk with elective cesarean (group 1) versus vaginal or emergency cesarean section (group 2), where three of them $[118,129]$ reported higher transmission risk with group 2, which was statistically significant in only 1 one of them.

On the other hand, other studies, including the European Pediatric Hepatitis C Virus Network study on 1,758 mothers and their infants, reported that delivery mode does not appear to influence the risk of transmission $[9,18,23,79,86]$.

\section{Management opportunities}

\section{Treatment regimens}

According to the recent 2018 ESPGHAN guidelines, Peg-IFN and RBV combination is no longer recommended for HCV treatment in children [17]. Today, DAAs are changing the image completely [15]. The ESPGHAN recommend that all treatment-naive and treatment-experienced children with chronic HCV infection be considered for therapy [17]. Liver biopsy is not routinely indicated in children with chronic HCV infection but it should be evaluated on a case-to-case basis. Treatment is considered without delay in presence of significant fibrosis and cirrhosis, extrahepatic manifestations and co-morbidities increasing the risk of rapid evolution of liver disease (solid organ or hematopoietic stem cell transplant recipients, other patients undergoing immunosuppressive treatments) [17].

\section{Target groups}

\section{HCV-PCR positive pregnant women}

- Pregnancy and the immediate post-partum period appear to be a highly unique period in the interaction between HCV and the chronically infected host. These periods appear to force some adaptation of the virus, due to the intense physiological changes, which may offer a therapeutic window when more suitable agents come into use [9].

- Peg-IFN and ribavirin therapy: They are no longer recommended for HCV treatment in adults in general [17] and pregnant women in particular. Peg-IFN can cause major psychiatric side effects during pregnancy, especially as pregnant females have a high susceptibility to postpartum depression [9]. Moreover, the injectable solution of Peg-IFN contains benzyl alcohol, which can be transmitted via the placenta and could cause infant toxicity [72]. On the other hand, ribavirin is absolutely contraindicated not only for HCV-infected pregnant women or childbearing women but also for HCV-infected men, whose partners may become pregnant due to its significant teratogenic effect [107]. With the era of DAAs, knowing the pregnant women's HCV status with subsequent treatment of mothers after delivery and clearing the $\mathrm{HCV}$ infection before subsequent pregnancies to completely eradicate HCV; vertical transmission in the future became a realistic strategy [15].

\section{HCV-PCR positive neonates and children}

Close follow-up of newborns to rule out vertical infection is essential for detection of pediatric $\mathrm{HCV}$, especially after the recently reported safety of DAAs in children as young as 6 years old [136].

\section{Treatment of infected females before pregnancy}

In the new era of DAAs, treatment of infected females before pregnancy seems to be an intelligent strategy.

\section{Preventive regimens}

In our opinion, DAAs' success and safety should encourage healthcare systems' standards of care to include universal screening of HCV during pregnancy. The benefits for women and their children should outweigh the additional costs for healthcare systems.

With successful treatment of the mother, there is the potential for completely eliminating vertical HCV transmission. At present, as treatment is not yet available during pregnancy, only children born from subsequent pregnancies would be protected, 
following antenatal diagnosis and treatment after delivery [15].

\section{Conclusions}

The HCV perinatal infection is an underestimated health problem which can lead to major chronic complications in later life. This necessitates intimate follow-up of all infants born to HCV-infected mothers by anti-HCV serology and PCR to apply timely management when needed. In areas with high HCV prevalence, a national screening program for HCV in females before marriage is warranted so as to start DAA treatment before marriage, which in turn can eradicate HCV vertical infection.

Understanding the modulatory effects of pregnancy on the immune response to HCV within the mother's liver as well as how HCV infects the fetal liver as it matures is necessary to allow better therapy.

The recently approved DAAs may open a new era of treatment of $\mathrm{HCV}$ infection during pregnancy in the near future. Universal HCV screening during pregnancy is a fair, realistic strategy which should be implemented in healthcare systems worldwide.

\section{Conflict of interest}

The authors declare no conflict of interest.

\section{References}

1. Kasprzak A, Rogacki K, Adamek A, et al. Tissue expression of beta-catenin and $\mathrm{E}$ - and $\mathrm{N}$-cadherins in chronic hepatitis C and hepatocellular carcinoma. Arch Med Sci 2017; 13: 1269-80.

2. Lavanchy D. Evolving epidemiology of hepatitis C virus Clin Microbiol Infect 2011; 17: 107-15.

3. Gower E, Estes C, Blach S, Razavi-Shearer K, Razavi H. Global epidemiology and genotype distribution of the hepatitis C virus infection. J Hepatol 2014; 61: S45-57.

4. Mohd Hanafiah K, Groeger J, Flaxman AD, Wiersma ST. Global epidemiology of hepatitis $C$ virus infection: new estimates of age-specific antibody to HCV seroprevalence. Hepatology 2013; 57: 1333-42.

5. Wedemeyer H, Dore GJ, Ward JW. Estimates on HCV disease burden worldwide - filling the gaps. J Viral Hepat 2015; 22 Suppl 1: 1-5.

6. Memon MI, Memon MAM. Hepatitis C an epidemiological review. J Viral Hepat 2002; 9: 84-100.

7. Luu L. Liver transplants. http://emedicine.medscape. com/article/776313-overview\#aw2aab6b2. Updated 4/2014. Accessed 8/2014.

8. Ghany M, Nelson D, Strader D, Thomas DL, Seeff LB. An update on treatment of genotype 1 chronic hepatitis C virus infection: 2011 practice guideline by the American Association for the Study of Liver Disease. Hepatology 2011; 54: 1433-44.

9. Arshad M, El-Kamary SS, Jhaveri R. Hepatitis C virus infection during pregnancy and the newborn period. Are they opportunities for treatment? J Viral Hepat 2011; 18: $229-36$
10. Bortolotti F, Verucchi G, Cammà C, et al.; Italian Observatory for HCV Infection and Hepatitis $\mathrm{C}$ in Children. Long-term course of chronic hepatitis $C$ in children: from viral clearance to end-stage liver disease. Gastroenterology 2008; 134: 1900-7.

11. Indolfi G, Resti M. Perinatal transmission of hepatitis $C$ virus infection. J Med Virol 2009; 81: 836-43.

12. Sookoian S. Liver disease during pregnancy: acute viral hepatitis. Ann Hepatol 2006; 5: 231-6.

13. Shukla S, Mehta G, Jais M, Singh A. A prospective study on acute viral hepatitis in pregnancy; seroprevalence, and fetomaternal outcome of 100 cases. J Biosci Tech 2011; 2: 279-286.

14. Canadian Paediatric Society. Vertical transmission of the hepatitis $C$ virus: current knowledge and issues. Paediatr Child Health 2008; 13: 529-34.

15. Aebi-Popp K, Duppenthaler A, Rauch A, De Gottardi A, Kahlert C. Vertical transmission of hepatitis C: towards universal antenatal screening in the era of new direct acting antivirals (DAAs)? Short review and analysis of the situation in Switzerland. J Virus Erad 2016; 2: 52-4.

16. Boaz K, Fiore AE, Schrag SJ, Gonik B, Schulkin J. Screening and counseling practices reported by obstetrician-gynecologists for patients with hepatitis $C$ virus infection. Infect Dis Obstet Gynecol 2003; 11: 39-44.

17. Indolfi G, Hierro L, Dezsofi A, et al. Treatment of chronic hepatitis $C$ virus infection in children: a position paper by the Hepatology Committee of European Society of Paediatric Gastroenterology, Hepatology and Nutrition. J Pediatr Gastroenterol Nutr 2018; 66: 505-15.

18. Ceci O, Margiotta M, Marello F, et al. Vertical transmission of hepatitis $C$ virus in a cohort of 2,447 HIV-seronegative pregnant women: a 24-month prospective study. J Pediatr Gastroenterol Nutr 2001; 33: 570-5.

19. European Pediatric Hepatitis C Virus Network. Three broad modalities in the natural history of vertically acquired hepatitis C virus infection. Clin Infect Dis 2005; 41: 45-51.

20. Mast EE, Hwang LY, Seto DS, et al. Risk factors for perinatal transmission of hepatitis $\mathrm{C}$ virus (HCV) and the natural history of HCV infection acquired in infancy. J Infect Dis 2005; 192: 1880-9.

21. England K, Thorne C, Newell ML. Vertically acquired paediatric coinfection with HIV and hepatitis $C$ virus. Lancet Infect Dis 2006; 6: 83-90.

22. Polywka S, Pembrey L, Tovo PA, Newell ML. Accuracy of HCV-RNA PCR tests for diagnosis or exclusion of vertically acquired HCV infection. J Med Virol 2006; 78: 305-10.

23. Zahran KM, Badary MS, Agban MN, Abdel Aziz NH. Pattern of hepatitis virus infection among pregnant women and their newborns at the Women's Health Center of Assiut University, Upper Egypt. Int I Gynaecol Obstet 2010; 111: 171-4.

24. LeCampion A, Larouche A, Fauteux-DanielS, Soudeyns H. Pathogenesis of hepatitis C during pregnancy and childhood. Viruses 2012; 4: 3531-50.

25. Floreani A. Hepatitis C and pregnancy. World J Gastroenterol 2013; 19: 6714-20.

26. Rein D, Wittenborn J, Weinbaum C, Sabin M, Smith BD, Lesesne SB. Forecasting the morbidity and mortality associated with prevalent cases of precirrhotic chronic hepatitis C in the United States. Digest Liver Dis 2011; 43: 66-72.

27. Denniston MM, Jiles RB, Drobeniuc J, et al. Chronic hepatitis $C$ virus infection in the United States, National Health and Nutrition Examination Survey 2003 to 2010. Ann Intern Med 2014; 160: 293. 
28. Locasciulli A, Gornati G, Tagger A, et al. Hepatitis C virus infection and chronic liver disease in children with leukemia in long-term remission. Blood 1991; 78: 1619-22.

29. Nelson SP, Jonas MM. Hepatitis C infection in children who received extracorporeal membrane oxygenation. J Pediatr Surg 1996; 31: 644-8.

30. Murray KF, Richardson LP, Morishima C, Owens JW, Gretch DR. Prevalence of hepatitis C virus infection and risk factors in an incarcerated juvenile population: a pilot study. Pediatrics 2003; 111: 153-7.

31. Ruiz-Extremera A, Salmerón J, Torres C, et al. Follow-up of transmission of hepatitis $C$ to babies of human immunodeficiency virus-negative women: the role of breast-feeding in transmission. Pediatr Infect Dis J 2000; 19: 511-6.

32. Sood A, Midha V, Bansal M, Sood N, Puri S, Thara A Perinatal transmission of hepatitis $C$ virus in northern India. Indian J Gastroenterol 2012; 31: 27-9.

33. Daw MA, Shawky S. Going beyond the curriculum to promote medical education and practice. Saudi Med 2002; 1: 116-7.

34. Daw MA, Dau AA. Hepatitis C virus in Arab world: a state of concern. Sci World J 2012; 2012: 719494.

35. Gasim GI, Murad IA, Adam I. Hepatitis B and C virus infections among pregnant women in Arab and African countries. J Infect Dev Ctries 2013; 7: 566-78.

36. Shobokshi OA, Serebour FE, Al-Drees AZ, Mitwalli AH, Qahtani A, Skakni LI. Hepatitis C virus seroprevalence rate among Saudis. Saudi Med J 2003; 24: 81-6.

37. Murad EA, Babiker SM, Gasim GI, Rayis DA, Adam I. Epidemiology of hepatitis $B$ and hepatitis $C$ virus infections in pregnant women in Sana'a, Yemen. BMC Pregnancy and Childbirth 2013; 13: 127.

38. Al-Kubaisy WA, Niazi AD, Kubba K. History of miscarriage as a risk factor for hepatitis $C$ virus infection in pregnant Iraqi women. East Mediterr Health J 2002; 8: 239-244.

39. Prasad MR, Honegger JR. Hepatitis $C$ virus in pregnancy. Am J Perinatol 2013; 30: 149-59.

40. Hughes BL, Page CM, Kuller JA. Hepatitis C in pregnancy: screening, treatment, and management. Am J Obstet Gynecol 2017; 217: B2-12.

41. Fernandes CN, Alves Mde M, de Souza ML, Machado GA, Couto G, Evangelista RA. Prevalence of seropositivity for hepatitis $B$ and $C$ in pregnant women. Rev Esc Enferm USP 2014; 48: 91-8.

42. Hofstraat SHI, Falla AM, Duffell EF, et al. Current prevalence of chronic hepatitis $B$ and $C$ virus infection in the general population, blood donors and pregnant wom en in the EU/EEA: a systematic review. Epidemiol Infect 2017; 145: 2873-85.

43. Kopilović B, Poljak M, Seme K, Klavs I. Hepatitis C virus infection among pregnant women in Slovenia: study on 31,849 samples obtained in four screening rounds during 1999, 2003, 2009 and 2013. Euro Surveill 2015; 20: 21144.

44. Ward C, Tudor-Williams G, Cotzias T, Hargreaves S, Regan L, Foster GR. Prevalence of hepatitis C among pregnant women attending an inner London obstetric department: uptake and acceptability of named antenatal testing. Gut 2000; 47: 277-80.

45. Kristiansen MG, Eriksen BO, Maltau JM, et al. Prevalences of viremic hepatitis $C$ and viremic hepatitis $B$ in pregnant women in Northern Norway. Hepatogastroenterology 2009; 56: 1141-5.

46. Salemovic D, Pesic-Pavlovic I, Jevtovic D, et al. Intravenous drug use an independent predictor for HCV gen- otypes 3 and 4 infection among HIV/HCV co-infected patients. Arch Med Sci 2017; 13: 652-8.

47. Wei L, Lok AS. Impact of new hepatitis C treatments in different regions of the world. Gastroenterology 2014; 146: $1145-50$

48. WHO for the Screening, Care and Treatment of Persons With Hepatitis C Infection. Geneva WHO; 2014.

49. Alrowaily MA, Abolfotouh MA, Ferwanah MS. Hepatitis $B$ virus sero-prevalence among pregnant females in Saudi Arabia. Saudi J Gastroenterol 2008; 14: 70-2.

50. AbdulOawi K, Youssef A, Metwally MA, Ragih I, AbdulHamid M, Shaheen A. Prospective study of prevalence and risk factors for hepatitis $C$ in pregnant Egyptian women and its transmission to their infants. Croat Med J 2010; 51: 219-28.

51. Yahia M. Global health: a uniquely Egyptian epidemic. Nature 2011; 474: 12-3.

52. Kamal SM, Nasser IA. Hepatitis C genotype 4: what we know and what we don't yet know. Hepatology 2008; 47: 1371-83.

53. Elsheikh RM, Daak AA, Elsheikh MA, Karsany MS, Adam I. Hepatitis B virus and hepatitis $C$ virus in pregnant Sudanese women. Virol J 2007; 4: 104.

54. Mudawi HM. Epidemiology of viral hepatitis in Sudan. Clin Exp Gastroenterol 2008; 1: 9-13.

55. Abou MA, Eltahir YM, Ali AS. Seroprevalence of hepatitis $B$ virus and hepatitis $C$ virus among blood donors in Nyala, South Dar Fur, Sudan. Virol J 2009; 6: 146.

56. Mesi A, Abudher A, El-Gadi S. The seroprevalence of HIV, HBV, and HCV, among pregnant women in Tripoli - Libya: are the Libyan babies at risk? AIDS - XVII International AIDS Conference 2008; Abstract no. CDC0137.

57. Elasifer HA, Agnnyia YM, Al-Alagi BA, Daw MA. Epidemiological manifestations of hepatitis $C$ virus genotypes and its association with potential risk factors among Libyan patients. Virol J 2010; 7: 317.

58. Alashek WA, Altagdi M. Risk factors and genotypes of hepatitis $C$ virus infection in Libyan patients. Libyan Med 2008; 080425: 162-5.

59. National Travel Network and Centre (NaTHNaC). Country information, Algeria, Tunisia and Kingdom of Morocco, 2009.

60. Hannachi N, Hidar S, Harrabi I, et al. Seroprevalence and risk factors of hepatitis $\mathrm{E}$ among pregnant women in central Tunisia. Pathol Biol 2011; 59: 115-8.

61. Ben Halima M, Arrouji Z, Slim A, Ben Redjeb S. Serotyping of hepatis $C$ virus in Tunisia. Tunis-Medindustrie 1998; 76: 200-3.

62. Djebbi A, Triki H, Bahri O, et al. Genotypes of hepatitis $C$ virus circulating in Tunisia. Epidemiol Infect 2003; 130: 501-5.

63. Benjelloun S, Bahbouhi B, Sekkat S, Bennani A, Hda N, Benslimane AA. Anti-HCV seroprevalence and risk factors of hepatitis C virus infection in Moroccan population groups. Res Virol 1996; 147: 247-55.

64. Bahri O, Ezzikouri S, Alaya-Bouafif NB, et al. First multicenter study for risk factors for hepatocellular carcinoma development in North Africa. World J Hepatol 2011; 3: 24-30.

65. Alter MJ. Epidemiology of hepatitis C virus infection. World J Gastroenterol 2007; 13: 2436-41.

66. Modi AA, Feld JJ. Viral hepatitis and HIV in Africa. AIDS Rev 2007; 9: 25-39.

67. Madhava V, Burgess C, Drucker E. Epidemiology of chronic hepatitis $C$ virus infection in sub-Saharan Africa. Lancet Infect Dis 2002; 2: 293-302.

68. Laurent C, Henzel D, Mulanga-Kabeya C, Maertens G, Larouzé B, Delaporte E. Seroepidemiological survey of 
hepatitis $\mathrm{C}$ among commercial sex workers and pregnant women in Kinshasa, Democratic Republic of Congo. Int J Epidemiol 2001; 30: 872-7.

69. Ndong-Atome GR, Makuwa M, Njouom R, et al. Hepatitis $C$ virus prevalence and genetic diversity among pregnant women in Gabon, central Africa. BMC Infect Dis 2008; 8: 82.

70. Ugbebor O, Aigbirior M, Osazuwa F, Enabudoso E, Zabayo $O$. The prevalence of hepatitis $B$ and $C$ viral infections among pregnant women. North Am J Med Sci 2011; 3: 238-41.

71. Okusanya BO, Aigere EO, Eigbefoh JO, Ikheloa J. Seroprevalence and clinico-epidemiological correlates of hepatitis C viral antibodies at an antenatal booking clinic of a tertiary hospital in Nigeria. Arch Gynecol Obstet 2013; 288: 495-500.

72. Collenberg E, Ouedraogo T, Ganamé J, et al. Seroprevalence of six different viruses among pregnant women and blood donors in rural and urban Burkina Faso: a comparative analysis. J Med Virol 2006; 78: 683-92.

73. Krause SK, Jones RK, Purdin SJ. Programmatic responses to refugees' reproductive health needs. Int Fam Plan Perspect 2000; 26: 181-7.

74. Bhargavi VR, Johari N, du Cros P, et al. Hepatitis C seroprevalence and HIV co-infection in sub-Saharan Africa: a systematic review and meta-analysis. Lancet Infect Dis 2015; 15: 819-24.

75. Munoz-Suano A, Hamilton AB, Betz AG. Gimme shelter: the immune system during pregnancy. Immunol Rev 2011; 241: 20-38.

76. Watanabe M, Iwatani Y, Kaneda T, et al. Changes in T, $B$, and NK lymphocyte subsets during and after normal pregnancy. Am J Reprod Immunol 1997; 37: 368-77.

77. Tovo PA, Calitri C, Scolfaro C, Gabiano C, Garazzino S. Vertically acquired hepatitis C virus infection: correlates of transmission and disease progression. World J Gastroenterol 2016; 22: 1382-92.

78. Paternoster DM, Santarossa C, Grella P, et al. Viral load in HCV RNA-positive pregnant women. Am J Gastroenterol 2001; 96: 2751-54.

79. Prasad MR, Honegger JR. Hepatitis C virus in pregnancy. Am J Perinatol 2013; 30: 149-59.

80. Okuyama R, Abo T, Seki S, et al. Estrogen activates extrathymic T cell differentiation in the liver. J Exp Med 1992; 175: 661-9.

81. Kimura M, Hanawa H, Watanabe H, Ogawa M, Abo T. Synchronous expansion of intermediate TCR cells in the liver and uterus during pregnancy. Cell Immunol 1995; 162: 16-25.

82. Tosone G, Maraolo AE, Mascolo S, Palmiero G, Tambaro O, Orlando R. Vertical hepatitis C virus transmission: Main questions and answers. World J Hepatol 2014; 6: 538-48.

83. Lin $\mathrm{HH}, \mathrm{KaO} \mathrm{JH}$. Hepatitis $\mathrm{C}$ virus load during pregnancy and puerperium. BJOG 2000; 107: 1503-6.

84. Irshad M, Khushboo I, Singh S, Singh S. Hepatitis C virus (HCV): a review of immunological aspects. Int Rev Immunol 2008; 27: 497-517.

85. Ropponen A, Sund R, Riikonen S, Ylikorkala O, Aittomäki K. Intrahepatic cholestasis of pregnancy as an indicator of liver and biliary diseases: a population-based study. Hepatology 2006; 43: 723-8.

86. Valladares G, Chacaltana A, Sjogren MH. The management of HCV-infected pregnant women. Ann Hepatol 2010; 9 Suppl: 92-7.

87. Floreani A, Paternoster D, Zappala F, et al. Hepatitis $\mathrm{C}$ virus infection in pregnancy. $\mathrm{Br}$ J Obstet Gynaecol 1996; 103: 325-9.
88. Luciani F, Alizon S. The evolutionary dynamics of a rapidly mutating virus within and between hosts: the case of hepatitis C virus. PLoS Comput Biol 2009; 5: e1000565.

89. Kage M, Ogasawara S, Kosai K, et al. Hepatitis C virus RNA present in saliva but absent in breast-milk of the hepatitis C carrier mother. J Gastroenterol Hepatol 1997; 12: 518-21.

90. Polywka S, Schröter M, Feucht HH, Zöllner B, Laufs R. Low risk of vertical transmission of hepatitis $C$ virus by breast milk. Clin Infect Dis 1999; 29: 1327-9.

91. Berkley EM, Leslie KK, Arora S, Qualls C, Dunkelberg JC. Chronic hepatitis C in pregnancy. Obstet Gynecol 2008; 112: 304-10.

92. Meunier JC, Bukh J, Diaz G, et al. Neutralizing antibodies to hepatitis C virus in perinatally infected children followed up prospectively. J Infect Dis 2011; 204: 1741-5.

93. Resti M, Jara P, Hierro L, et al. Clinical features and progression of perinatally acquired hepatitis $C$ virus infection. J Med Virol 2003; 70: 373-7.

94. Azzari C, Resti M, Moriondo M, Ferrari R, Lionetti P, Vierucci A. Vertical transmission of HCV is related to maternal peripheral blood mononuclear cell infection. Blood 2000; 96: 2045-8.

95. Bevilacqua E, Fabris A, Floreano P, et al.; EPHN collaborators. EPHN collaborators Genetic factors in motherto-child transmission of HCV infection. Virology 2009; 390: 64-70.

96. Indolfi G, Sambrotta M, Moriondo M, Azzari C, Resti M. Genetic variation in interleukin-28B locus is associated with spontaneous clearance of HCV in children with non-1 viral genotype infection. Hepatology 2011; 54: 1490-1.

97. Mangia A. IL28B: A new wager in the skyline of hepatitis C virus infection. Dig Liver Dis 2011; 43: 177-9.

98. Ruiz-Extremera A, Muñoz-Gámez JA, Salmerón-Ruiz MA, et al. Genetic variation in interleukin 28B with respect to vertical transmission of hepatitis $C$ virus and spontaneous clearance in HCV-infected children. Hepatology 2011; 53: 1830-8.

99. Hurtado CW, Golden-Mason L, Brocato M, Krull M, Narkewicz MR, Rosen HR. Innate immune function in placenta and cord blood of hepatitis C - seropositive mother-infant dyads. PLoS One 2010; 5: e12232.

100. Prasad MR, Honegger JR. Hepatitis C virus in pregnancy. Am J Perinatol 2013; 30: 149-59.

101. Hayashida A, Inaba N, Oshima K, et al. Re-evaluation of the true rate of hepatitis $C$ virus mother-to-child transmission and its novel risk factors based on our two prospective studies. J Obstet Gynaecol Res 2007; 33: 417-22.

102. Parthiban R, Shanmugam S, Velu V, et al. Transmission of hepatitis $C$ virus infection from asymptomatic mother to child in southern India. Int J Infect Dis 2009; 13: 394-400.

103. Zanetti AR, Tanzi E, Newell ML. Mother-to-infant transmission of hepatitis C virus. J Hepatol 1999; 31: 96-100.

104. Indolfi G, Nesi A, Resti M. Intrafamilial transmission of hepatitis C virus. J Med Virol 2013; 85: 608-14.

105. Inui A, Fujisawa T, Sogo T, Komatsu H, Isozaki A, Sekine I. Different outcomes of vertical transmission of hepatitis C virus in a twin pregnancy. J Gastroenterol Hepatol 2002; 17: 617-9.

106. Pembrey L, Newell ML, Tovo PA; EPHN Collaborators. The management of HCV infected pregnant women and their children. European paediatric HCV network. J Hepatol 2005; 43: 515-25. 
107. Babik JM, Cohan D, Monto A, Hartigan-O'Connor DJ, McCune JM. The human fetal immune response to hepatitis C virus exposure in utero. J Infect Dis 2011; 203: 196-206.

108. Dal Molin G, D’Agaro P, Ansaldi F, Ciana G, Fertz C, Alberico S, Campello C. Mother-to-infant transmission of hepatitis $C$ virus: rate of infection and assessment of viral load and IgM anti-HCV as risk factors. J Med Virol 2002; 67: 137-42

109. Azzari C, Moriondo M, Indolfi G, et al. Higher risk of hepatitis $C$ virus perinatal transmission from drug user mothers is mediated by peripheral blood mononuclear cell infection. J Med Virol 2008; 80: 65-71.

110. Indolfi G, Azzari C, Moriondo M, Lippi F, de Martino M, Resti M. Alanine transaminase levels in the year before pregnancy predict the risk of hepatitis $C$ virus vertical transmission. J Med Virol 2006; 78: 911-4.

111. Resti M, Azzari C, Mannelli F, et al. Mother to child transmission of hepatitis $C$ virus: prospective study of risk factors and timing of infection in children born to women seronegative for HIV-1. Tuscany Study Group on Hepatitis C Virus Infection. BMJ 1998; 317: 437-41.

112. Shebl FM, El-Kamary SS, Saleh DA, et al. Prospective cohort study of mother-to-infant infection and clearance of hepatitis $C$ in rural Egyptian villages. J Med Virol 2009; 81: 1024-31.

113. European Paediatric Hepatitis C Virus Network. A significant sex - but not elective cesarean section - effect on mother-to-child transmission of hepatitis $\mathrm{C}$ virus infection. J Infect Dis 2005b; 192: 1872-9.

114. Granovsky MO, Minkoff HL, Tess BH, et al. Hepatitis C virus infection in the mothers and infants cohort study. Pediatrics 1998; 102: 355-9.

115. Rainey WE, Rehman KS, Carr BR. Fetal and maternal adrenals in human pregnancy. Obstet Gynecol Clin N Am 2004; 31: 817-35.

116. Steininger $C$, Kundi $M$, Jatzko $G$, Kiss $H$, Lischka $A$, Holzmann $\mathrm{H}$. Increased risk of mother-to-infant transmission of hepatitis $C$ virus by intrapartum infantile exposure to maternal blood. J Infect Dis 2003; 187: 345-51.

117. Klein SL. Hormones and mating system affect sex and species differences in immune function among vertebrates. Behav Processes 2000; 51: 149-66.

118. McMenamin MB, Jackson AD, Lambert J, et al. Obstetric management of hepatitis C-positive mothers: analysis of vertical transmission in 559 mother-infant pairs. Am J Obstet Gynecol 2008; 199: 315.

119. Mariné-Barjoan E, Berrebi A, Giordanengo V, et al. HCV/HIV co-infection, HCV viral load and mode of delivery: risk factors for motherto-child transmission of hepatitis C virus? AIDS 2007; 21: 1811-5.

120. Polis CB, Shah SN, Johnson KE, Gupta A. Impact of maternal HIV coinfection on the vertical transmission of hepatitis C virus: a metaanalysis. Clin Infect Dis 2007; 44: 1123-31.

121. Ngo-Giang-Huong N, Jourdain G, Sirirungsi W, et al. Human immunodeficiency virus-hepatitis C virus co-infection in pregnant women and perinatal transmission to infants in Thailand. Int J Infect Dis 2010; 14: 602-7.

122. Lo Re V $3^{\text {rd }}$, Kostman JR, Amorosa VK. Management complexities of HIV/hepatitis C virus coinfection in the twenty-first century. Clin Liver Dis 2008; 12: 587-609.

123. Bosi I, Ancora G, Mantovani W, et al. Italian observatory for HCV infection and hepatitis $C$ in children. HLA DR13 and HCV vertical infection. Pediatr Res 2002; 51: 746-9.
124. Mok J, Pembrey L, Tovo PA, Newell ML. When does mother to child transmission of hepatitis $C$ virus occur? Arch Dis Child Fetal Neonatal Ed 2005; 90: 156-60.

125. Okamoto M, Nagata I, Murakami J, et al. Prospective reevaluation of risk factors in mother-to-child transmission of hepatitis $C$ virus: high virus load, vaginal delivery, and negative anti-NS4 antibody. J Infect Dis 2000; 182: 1511-4.

126. Shiraki K, Ohto $\mathrm{H}$, Inaba N, et al. Guidelines for care of and guidance for pregnant women carrying hepatitis $C$ virus and their infants. Pediatr Int 2008; 50: 138-40.

127. Della Bella S, Riva A, Tanzi E, et al. Hepatitis C virus-specific reactivity of CD4+-lymphocytes in children born from HCV-infected women. J Hepatol 2005; 43: 394-402.

128. Cottrell EB, Chou R, Wasson N, Rahman B, Guise JM. Reducing risk for mother-to-infant transmission of hepatitis C virus: a systematic review for the U.S. Preventive Services Task Force. Ann Intern Med 2013; 158: 109-13.

129. Gibb DM, Goodall RL, Dunn DT, et al. Mother-to-child transmission of hepatitis C virus: evidence for preventable peripartum transmission. Lancet 2000; 356: 904-7.

130. Lin $\mathrm{HH}, \mathrm{Kao} \mathrm{JH}, \mathrm{Hsu} \mathrm{HY}$, et al. Absence of infection in breast-fed infants born to hepatitis $C$ virus-infected mothers. J Pediatr 1995; 126: 589-91.

131. Spencer JD, Latt N, Beeby PJ, et al. Transmission of hepatitis $C$ virus to infants of human immunodeficiency virus-negative intravenous drugusing mothers: rate of infection and assessment of risk factors for transmission. J Viral Hepat 1997; 4: 395-409.

132. European Paediatric Hepatitis C Virus Network. Effects of mode of delivery and infant feeding on the risk of mother-to-child transmission of hepatitis C virus. European Paediatric Hepatitis C Virus Network. BJOG 2001; 108: 371-7.

133. Yeung LT, King SM, Roberts EA. Mother-to-infant transmission of hepatitis C virus. Hepatology 2001; 34: 223-9.

134. Pfaender S, Heyden J, Friesland $M$, et al. Inactivation of hepatitis $C$ virus infectivity by human breast milk. J Infect Dis 2013; 208: 1943-52.

135. Connor EM, Sperling RS, Gelber R, et al. Reduction of maternal-infant transmission of human immunodeficiency virus type 1 with zidovudine treatment. Pediatric AIDS Clinical Trials Group Protocol 076 Study Group. N Engl J Med 1994; 331: 1173-80.

136. El-Shabrawi MHF, Kamal NM, El-Khayat HR, Kamal EM, AbdElgawad MMAH, Yakoot M. A pilot single arm observational study of sofosbuvir/ledipasvir $(200+45 \mathrm{mg})$ in 6- to 12-year old children. Aliment Pharmacol Ther 2018; 47: 1699-704. 